\title{
Pentingnya Lingkungan dalam Pembelajaran Bahasa Indonesia
}

Lingkungan adalah sesuatu yang penting bagi manusia yang mencakup semua sumber daya alam seperti flora, fauna, air, dan sebagainya. Lingkungan pun akan menjadi momok apabila mengalami masalah yang serius. Menurut Mitsuki dan Lai (dalam Ramadhan et al, 2019) di seluruh dunia, semua orang menghadapi masalah lingkungan yang serius, seperti pemanasan global, hujan asam, perusakan lapisan ozon, pencemaran lingkungan, kerusakan alam, dan hilangnya keanekaragaman hayati yang bisa serius. Contohnya saja yang terjadi di Indonesia saat ini, yaitu kerusakan hutan. Kerusakan hutan terjadi karena adanya Pembalakan liar atau illegal logging serta pembakaran hutan yang menyebabkan berkurangnya lahan hutan, pencemaran udara akibat kabut asap pembakaran hutan, dan matinya fauna seperti ular, monyet, babi, dan sebagainya.

Kerusakan lingkungan disebabkan karena adanya aktivitas manusia yang ceroboh dalam meningkatkan taraf hidupnya serta kurangnya kesadaran terhadap lingkungan. Untuk itu, dalam mengurangi kecerobohan dan meningkatkan kesadaran manusia diperlukannya pendidikan lingkungan. Menurut Nkwetisma (dalam Ramadhan et al, 2019) Pendidikan lingkungan adalah upaya bersama yang secara sadar diselenggarakan untuk mengajarkan atau menarik perhatian manusia tentang bagaimana fungsi lingkungan alam dan bagaimana manusia ini dapat mengelola dan melindunginya.

Kaitan antara pendidikan lingkungan dengan pembelajaran Bahasa Indonesia adalah mengajarkan materi lingkungan melalui teks-teks bacaan dalam pembelajaran bahasa, dan secara representatif memberikan gambaran betapa kayanya pengetahuan manusia terhadap alam, baik itu melalui pendidikan formal maupun informal. Melalui pendidikan formal biasanya yang berperan adalah guru sedangkan dalam pendidikan informal yang berperan adalah semua kalangan yang mampu melakukan pengintegrasian lingkungan dengan pembelajaran.

Untuk memperkuat pernyataan tentang pentingnya lingkungan dengan pembelajaran Bahasa indonesia, penulis membuat angket dengan sasaran mahasiswa dan memberikan 10 pertanyaan dengan tema lingkungan, setelah angketnya disebar penulis mendapat 39 responden dari kalangan mahasiswa S1 dan S2 dengan jurusan yang beragam dari berbagai Universitas di 
Indonesia dengan persentase $64,1 \%$ wanita dan $35.9 \%$ pria. Berdasarkan pertanyaan yang diajukan penulis, 45,9\% Mahasiswa menyatakan sangat setuju jika teks narasi dibuat dengan tema lingkungan, $27 \%$ menyatakan setuju, 24,3\% menyatakan kurang setuju dan hanya 2,4\% menyatakan tidak setuju. Dari hasil pertanyaan pertama, selanjutnya untuk pertanyaan kedua $45.9 \%$ Mahasiswa menyatakan sangat setuju dan setuju jika karya sastra dibuat dengan mengamati lingkungan, 5,4 \% kurang setuju dan sisanya 2,4\% tidak setuju. Selanjutya untuk pertanyaan ketiga, 54,1\% Mahasiswa menyatakan sangat setuju jika karya sastra dihidupkan dengan tema lingkungan, 32,4\% menyatakan setuju dan 13,5\% menyatakan kurang setuju. Hasil untuk pertayaan keempat, 59,5\% Mahasiswa menyatakan sangat setuju jika lingkungan menjadi inspirasi dalam membuat karya sastra, 53,1\% menyatakan setuju, dan 2,7\% menyatakan kurang setuju dan tidak setuju, selanjutnya untuk pertanyaan kelima, 54,1 \% Mahasiswa menyatakan sangat setuju mengambil objek yang unik dalam lingkungan dalam pembuatan cerpen, $27 \%$ menyatakan setuju, dan 18,9 \% kurang setuju. Untuk pertanyaan keenam, 82,1\% menyatakan iya jika dongeng kancil berkaitan dengan lingkungan, 10,3\% menyatakan tidak, dan 7,7\% menyatakan mungkin. Untuk pertanyaan ketujuh, 61,5 Mahasiswa mengetahui kesesuai pembaca dengan tema lingkungan dan selebihnya tidak mengetahui, selanjutnya pertanyaan kedelapan, 76,9 \% Mahasiswa belajar mengamati lingkungan dalam pembuatan karya sastra dan 2,5\% menyatakan tidak. Pertanyaan kesembilan, 66,7 Mahasiswa mampu membuat buku dengan tema lingkungan, 23,1\% menyatakan mungkin, dan sisanya tidak. Untuk pertanyaan kesepuluh, 84,6\% Mahasiswa menyatakan ya jika cerita rakyat berelevansi dengan lingkungan, dan 15,4\% menyatakan mungkin.

Berdasarkan hasil angket yang dibuat penulis, dapat disimpulkan bahwa Mahasiswa juga harus mengetahui pentingnya lingkungan dengan pembelajaran Bahasa Indonesia sekalipun bukan dari jurusan Bahasa Indonesia serta mampu mengintegrasikan lingkungan dengan pembelajaran Bahasa Indonesia dengan cara membuat teks bacaan seperti cerpen, puisi, narasi dan sebagainya dengan tema lingkungan, dengan hal ini secara langsung dapat memicu minat siswa dalam mempelajari bahasa dan secara tidak langsung dapat meningkatkan pengetahuan siswa tentang lingkungan sehingga siswa sadar akan pentingnya melestarikan lingkungan dengan hal ini juga akan menimalisir adanya masalah lingkungan di masa yang akan datang. 


\section{Daftar Rujukan}

Ramadhan, S., Sukma, E., \& Indriyani, V. (2019) Enviromental education and disastermitigation through language learning. IOP Conference Series: Earth and Environmental Science, 314. 